UDC 811.111'27:656.61

DOI https://doi.org/10.24919/2308-4863/35-7-38

Olena FROLOVA, orcid.org/0000-0002-1510-2902

Candidate of Pedagogical Sciences, Associate Professor at the English Language Department for Deck Officers Kherson State Maritime Academy (Kherson,Ukraine) olenafrolova09@gmail.com

\title{
TEACHING STANDARD MARITIME COMMUNICATION PHRASES AT MARITIME ENGLISH LESSONS
}

Modern maritime industry is international, a great number of crews are multilingual, a lot of maritime accidents are caused by communication barriers. The diversity in ship and shore personnel engaged in maritime transportation may subsequently result in communication problems. Communication failures together with the differences in accents of English may affect safety of human life and marine environment. Standard Marine Communication Phrases (SMCP) were adopted by the International Maritime Organization in order to reduce such risks.

The paper deals with the ways of teaching SMCP at Maritime English lessons. The author points out that the training of SMCP should be carried out systematically. As it is necessary to develop a thematically oriented and methodically grounded system of training activities, to determine the sequence of their application in the classroom.

The author of the paper shares the experience of implementing communicative activities in order to provide trainees with "command of English in written and oral form" necessary to perform profession-oriented duties and meet industry requirements listed in the STCW Convention. The advantages of certain types of exercises and activities presented in the IMO Model Course 3.17 "Maritime English" are discussed. In addition to controlled and semi-controlled exercises, Maritime English teachers are recommended to use role-plays and simulations based on real-life situations.

The paper focuses on training of future seamen in SMCP knowledge for enhancing their communication skills in routine and emergency situations which would help prevent possible accidents due to communication failures. The basic aim is to describe how SMCP can be incorporated in the learning process of Maritime English in order to prevent communication failures. Trainees should be engaged into a real-life maritime scenario simulation, provided with an opportunity to apply a broader set of professional knowledge.

The paper will also present outcomes of training sessions conducted at Maritime English lessons in which SMCP were practiced by trainees.

Key words: Maritime English, Standard Marine Communication Phrases, multilingual crew, authentic material, communicative activities.

Олена ФРОЛОВА, orcid.org/0000-0002-1510-2902 кандидат педагогічних наук, доиент кафедри англійської мови в судноводінні Херсонської державної морської академії (Херсон, Україна) olenafrolova09@gmail.com

\section{НАВЧАННЯ СТАНДАРТНИХ ФРАЗ ДЛЯ СПІЛКУВАННЯ НА МОРІ НА ЗАНЯТТЯХ ІЗ МОРСЬКОЇ АНГЛІЙСЬКОЇ МОВИ}

Сучасна морська галузь є міжнародною, велика кількість екіпажів є багатомовними, багато морських аварій спричинені комунікаційними бар'єрами. Різноманіття суднового та берегового персоналу, щчо займається морськими перевезеннями, згодом може призвести до проблем у комунікації. Невдачі в спілкуванні разом із різницею в акцентах англійської мови можуть вплинути на безпеку життя людей $і$ морського середовища. 3 метою зменшення таких ризиків Міжнародна морська організація затвердила Стандартні фрази для спілкування на морі.

У статті розглядаються способи навчання стандартних фраз для спілкування на морі на заняттях із морської англійської мови. Авторка зазначає, щчо навчання стандартних фраз має проводитися систематично, оскільки необхідно розробити тематично орієнтовану та методично обтрунтовану систему навчальних завдань, визначити послідовність їх застосування на занятті.

Авторка статті ділиться досвідом використання комунікативних завдань з метою забезпечення майбутніх моряків «володінням англійською мовою в письмовій та усній формі», необхідним для виконання професійно- 
оріснтованих обов 'язків і задоволення галузевих вимог, перелічених у Конвенції ПДНВ. Обговорюються переваги деяких видів вправ і завдань, представлених у Модельному курсі ІМО 3.17 «Морська англійська мова». Додатково до контрольованих $і$ напівконтрольованих вправ викладачам морської англійської мови рекомендується використовувати рольові та імітаційні ігри на основі реальних ситуацій.

Стаття зосереджена на навчанні майбутніх моряків стандартних фраз для спілкування на морі для підвищення їхніх навичок спілкування в повсякденних $і$ надзвичайних ситуачіях, щзо допомогло б запобігти можливим аваріям унаслідок непорозумінь. Основна мета статті полягає в тому, щзб описати, як навчання стандартних фраз може бути включено в процес навчання морської англійської мови. Здобувачі повинні брати участь у реальному моделюванні професійного сценарію, щзо забезпечує можливість застосовування широкого набору професійних знань.

Також представлені результати навчальних занять із морської англійської мови, на яких здобувачі практикували стандартні фрази для спілкування на морі.

Ключові слова: морська англійська мова, стандартні фрази для спілкування на морі, багатомовний екіпаж, автентичний матеріал, комунікативні вправи.

Problem statement. Among the main tasks of modern maritime education and training is to facilitate safer navigation worldwide, thus the International Maritime Organization (IMO) has outlined that effective communication is an essential issue for maritime safety. Standard Marine Communication Phrases (SMCP) serve as "the language for the sea", as they improve and standardize Maritime English. Today it is required that each seafarer should demonstrate SMCP competency regardless of his rank, nationality and field of work. There is a current need in clear, accurate on-board communication and successful interaction among the crewmembers because a lot of accidents at sea are caused by communication misunderstandings. The SMPC course should be integrated logically into the course of Maritime English within the curriculum of maritime institutions.

The main focus must be on the development of successive and systematic teaching and learning materials in SMCP. The improvement of such materials as guidelines for maritime communication in multilingual crews must be carried out dynamically and continually.

The author of the paper suggests a number of activities focused on learning of SMCP, analyzes the communicative skills required by the IMO Model Course 3.17 in order to ground selected activities for Maritime English lessons. The results of the analysis will be presented in the paper.

Recent research and publications. The question of the standardization of Maritime English, the objectives and challenges of SMCP use have been discussed by C. Cole, A. Noble, B. Pritchard, P. Trenkner and many others. A. Sihmantepe, S. Sernikli, R. Ziarati present outcomes of communication training sessions conducted in a bridge simulator in which SMCP were practiced in a 'building-up' manner through a passage scenario (Şihmantepe et al., 2011).

Many papers discuss the purpose of SMCP in enhancing safety of navigation, study their lexi- cal and grammar features (Pritchard, 2002). Some researchers focus on the peculiarities of maritime VHF communication and an urgent need in effective training of future seamen for a diverse professional environment at sea (Şihmantepe et al., 2019). Some authors share their own experience of developing such learning activities that can assist in SMCP training in maritime institutions (Kudryavtseva, Shvetsova, 2019).

The purpose of the research is to present the results of the implementation of activities in the process of SMCP training.

The main text. According to the International Convention on Standards of Training, Certification and Watchkeeping for Seafarers, the ability to understand and use SMCP is required for the certification of officers in charge of a navigational watch on ships of 500 gross tonnage or above (STCW, 2011). SMCP include phrases which have been developed to cover the most important safety-related fields of verbal shore-to-ship (and vice-versa), ship-to-ship and onboard communications (SMCP, 2002).

It is extremely important that together with external VHF communication with the shore stations and the other ships in the area of sailing, continuous communication must also be established between the bridge and the engine control room during the passage. Besides, clear and comprehensible verbal communication within the bridge and engine control room must ensure safe navigation of the ship. The crewmembers must be able to perform operational communications clearly, like handing over the watch, reporting faults, contacts and incidents etc. (Şihmantepe et al., 2011: 107).

Since SMCP explain the procedures on routine and emergency on-board communication, it is not enough to focus on accurate use of SMCP only. It is obvious that every seaman must be competent in the use of SMCP as he/she must be ready for the challenges facing modern multilingual maritime industry. 
SMCP training at Maritime English lessons can provide an opportunity to create a real-life professional language context for trainees. The process of SMCP learning can simulate the actual work of the ship and the trainees can use them in their future onboard work. In order to achieve good results, the Maritime English teachers should adjust the syllabus of SMCP training, use the authentic materials and select the training content.

For instance, Uwe-Michael Witt in his research paper suggests how the methodical approach can be implemented into the process of SMCP training. The approach can be divided into four stages: comprehending stage, imprinting stage, acquiring stage and using stage (Witt, 2019: 218).

The Comprehending Stage is a sequence of staged communications based on single-purpose communications in the scenario. The learner has to complete certain exercises (multiple choice, true/false, gaps fill) while listening. After each exercise completion, the learner listens to the communication again and reads along the tape script.

The Imprinting Stage is a sequence of exercises during which the learner's focus is directed to the specific meaning of words. Examples of SMCP are quoted to illustrate the unique meaning of the words. Secondly, VHF communication is practiced (e.g. message markers, etc.). The accurate use of tense forms is practiced as well as the correct use of prepositions. All exercises are based on one message which was presented at the Comprehending Stage. The learner is also invited to repeat it as a practice for the pronunciation.

The Acquiring Stage includes only one type of exercise: the learner repeats the complete message after a native speaker has read it to give the perfect pronunciation example.

The Using Stage is a sole translation exercise: the learner translates from his/her mother tongue the messages used in all three stages before. (Witt, 2019: 218).

To the author's opinion, SMCP training shall be thoroughly planned by the teacher. As it is necessary to collect the appropriate authentic material and create typical working situations at Maritime English lesson. According to the training purpose, the teacher is highly advised to select communicative tasks available in IMO Model Course 3.17. The author recommends that the process of SMCP training should be divided into four stages: lead-in (motivation activities), presentation (drilling exercises), practice (practicing SMCP dialogues) and production (free application of SMCP in professional speaking).
The Part "Instructor Manual" of IMO Model Course 3.17 contains 25 various communicative activities focused on accuracy and fluency of use of SMCP (IMO Model Course, 2015). These activities can be grouped as follows:

1) SMCP drilling (individual drills, open and closed pair drills, choral drills, split class drills, back chaining drills, contrasting drills, substitutional drills, drilling SMCP with audio recordings);

2) Surveys (group questionnaires, class survey);

3) Dialogues (half dialogues, vanishing dialogue, guided dialogues, collaborative dialogues, SMCP dialogue prompts);

4) Dictations ("thinking" dictation, student-led dictation, pair race dictation, wall dictations, split pair dictation);

5) Simulation and role-play (guided SMCP roleplays, free SMCP role-plays, checklist simulation);

6) Others (random choice communications, transferring messages to SMCP, students' recordings, SMCP comprehension activities, taking notes, SMCP message markers).

However, the Maritime English teacher shall choose a number of activities to succeed in SMCP training. Based on the author's experience, the sequence of SMCP training shall be logical and effective. For example, the series of activities (minimum 5) can be helpful to drill one set of SMCP (Frolova, 2020: 213).

For example, within the topic "Standard Engine Orders", the students are assigned a number of leadin tasks first. The students are free in expressing their own opinions.

\section{List top-three situations when deck and engine officers} must maintain efficient communication.

\section{Discuss the questions.}

1. How is it possible to coordinate the actions between departments?

2. What device(s) can be used for internal communication?

3. Why must the orders be standardized?

Answer the question.

1. Which of the phrases are engine orders? Why?

- Port fifteen

- Stop engines

- What is your position?

- How do you read me?

- Half ahead

- Meet her

- Starboard ten

Slow astern

Then the teacher is recommended to apply traditional choral drilling and follow with substitutional drills. Both these activities are considered to be fully controlled activities. 
Listen to the engine orders and repeat them. Listen to the engine orders and write them down. Listen to the engine orders and underline the correct option.

1. a) You must be fully prepared to manoeuvre.

b) You must proceed slowly ahead.

2. a) You must reverse very slowly.

b) You must reverse at top speed.

3. a) No more manoeuvring.

b) No engine revolutions.

4. a) You must reverse slowly.

b) You must proceed with maximum manoeuvring speed.

Then the teacher may continue with semi-controlled activities (e.g. half dialogues, SMCP dialogue prompts).

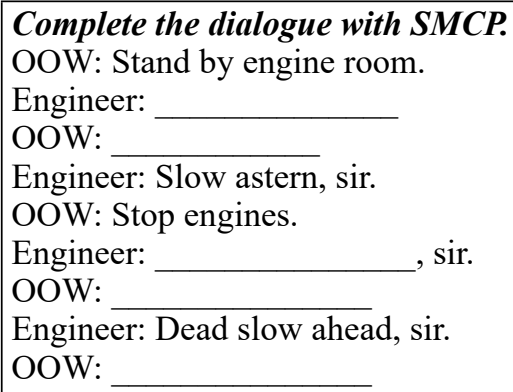

At the final stage, the productive activities must be applied by the teacher (e.g. guided SMCP role-plays, free SMCP role plays). When preparing guided SMCP role plays, the teacher shall prepare a guided dialogue using SMCP and also some simple role cards to vary the information contained in the dialogue. Once the trainees have completed and practised the guided dialogue, the teacher shall hand out the role play cards to pairs of students and ask them to try the dialogue again but using the new information they have on their cards. Free SMCP role plays require a list of sit- uations onboard a vessel that would require seafarers to use SMCP. To make the situations more realistic, the authentic context is required. The students should work in pairs, improvising a suitable dialogue using appropriate SMCP.

\section{Role-play the situations. \\ Situation 1 \\ Student A. You are OOW. Order the engine room to slow down, then stop and then shut down the engines. Student B. You are Engineer. Respond to OOW. \\ Situation 2 \\ Student A. You are OOW. Order the engine room to get ready, then go in reverse, stop, then go slowly forward. Student B. You are Engineer. Respond to OOW.}

The sequence of activities suggested by the author in the process of SMCP training is aimed at linking real seafarer's life and classroom environment. The activities recommended above can serve as a compulsory part of Maritime English course.

Conclusion. The author outlined the way the process of learning SMCP can be organized within the course of Maritime English. SMCP drilling makes the learning environment of Maritime English classroom similar to that of a ship's one, it provides professional scenarios of communication in the maritime industry. The trainees are supposed to use the learnt SMCP during their academic training (navigation sciences) and apply them in real-life situations (internal and external maritime communication).

As for the further research, the author will study the problem of the article deeper in her next publications. The opportunities of improving SMCP competency of future seamen by means of training sessions within bridge simulators and application of real-life scenarios will be analyzed.

\section{BIBLIOGRAPHY}

1. IMO Model Course 3.17. Maritime English. London : International Maritime Organization, 2015. 228 p.

2. IMO Standard Marine Communication Phrases. London : IMO Publishing, 2002. 116 p.

3. Pritchard B. On Some Issues in the Standardization of Maritime English - Pedagogical Implications. Proceedings of International Seminar on Maritime English. 2002. P. 52-68.

4. Şihmantepe A., Beşikçi E.B., Özsever E. Efficiency of IMO SMCP for safe navigation at sea: needs and challenges. Молодий вчений. 2019. Вип. 7.2 (71.2). С. 25-29.

5. Şihmantepe A., Sernikli S., Ziarati R. Building Maritime English by Event Simulation. Proceedings of IMEC-23. 2011. P. 102-112.

6. STCW including 2010 Manila amendments: STCW Convention and STCW Code. London : International Maritime Organization, 2011.

7. Witt U. M. My Practice: Using Tailor-Made Exercise Sequences Provided Online to Improve, Practice and Consolidate the Use of the SMCP at VTS and MRC and Port Control Centres. Proceedings of IMEC-31. 2019. P. 214-220.

8. Кудрявцева В. Ф., Швецова I. В. Стандартні фрази для спілкування на морі як навчальна потреба. Педагогічні науки. 2019. Вип. LXXXVIII. C. 104-109.

9. Фролова О. O. Integrating Standard Marine Communication Phrases into Maritime English Course. Педагогіка формування творчої особистості у вищій і загальноосвітній иколах. 2020. Вип. 68. Т. 2. С. 212-215. 


\section{Пенагогіка}

\section{REFERENCES}

1. IMO Model Course 3.17. Maritime English. London: International Maritime Organization, 2015. 228 p.

2. IMO Standard Marine Communication Phrases. London: IMO Publishing, 2002. 116 p.

3. Pritchard B. On Some Issues in the Standardization of Maritime English - Pedagogical Implications. Proceedings of International Seminar on Maritime English. 2002. pp. 52-68.

4. Şihmantepe A., Beşikçi E.B., Özsever E. Efficiency of IMO SMCP for safe navigation at sea: needs and challenges. Young Scientist. 2019. Issue 7.2 (71.2). pp. 25-29.

5. Şihmantepe A., Sernikli S., Ziarati R. Building Maritime English by Event Simulation. Proceedings of IMEC-23. 2011. pp. $102-112$.

6. STCW including 2010 Manila amendments: STCW Convention and STCW Code. London: International Maritime Organization, 2011

7. Witt U.M. My Practice: Using Tailor-Made Exercise Sequences Provided Online to Improve, Practice and Consolidate the Use of the SMCP at VTS and MRC and Port Control Centres. Proceedings of IMEC-31. 2019. pp. 214-220.

8. Kudryavtseva V.F., Shvetsova I.V. Standartni frazy dlja spilkuvannja na mori jak navchal'na potreba [Standard Maritime Communication Phrases as a Training Need]. Pedagogical Sciences. 2019. Issue LXXXVIII. pp. 104-109 [in Ukrainian].

9. Frolova O.O. Integrating Standard Marine Communication Phrases into Maritime English Course. Pedagogy of Creative Personality Formation in Higher and Secondary Education. 2020. Issue 68. Volume 2. pp. 212-215. 